\title{
Turntablism in the History of International Law
}

\author{
Jean d'Aspremont
}

\begin{abstract}
This chapter uses the metaphor of turntablism to shed light on the confinement of international lawyers' engagement with history to the terms, vocabularies, and categories of the very historical narratives they seek to evaluate, disrupt, or displace. For the sake of this chapter, turntablism is understood here as the art of creating new music and sound effects by using one or several turntables on which a record is placed. This chapter argues that twenty-first century international lawyers engaging with the history of international law are talented turntablists in that the many historiographical works of international lawyers produced since the so-called 'historical turn' have remained confined to the very terms, categories, and vocabularies of the histories whose creation they have been discoursing and theorising. This chapter ultimately shows that turntablism is not the inevitable fate of international lawyers engaging with history, and that a radical historical critique is possible and should be promoted.
\end{abstract}

\section{Keywords}

international law - history - historiography - critique - critical legal studies - critical histories - colonialism - Eurocentricism

Turntablism is the art of creating new music and sound effects by using one or several turntables on which a record is placed. The so-called turntablists better known as DJs - manipulate records on turntables by moving them with their hand to cue the stylus to exact points thereon, and by touching or moving the record to stop, slow down, speed up, or spin the record backwards. ${ }^{1}$ Using

1 On the notion of turntablism, see generally Holmes, Thom. Electronic and Experimental Music: Technology, Music, and Culture (Abingdon: Routledge, 2015), 476-483. 
the metaphor of turntablism for descriptive purposes, this chapter argues that twenty-first century international lawyers engaging in the history of international law are talented turntablists and that the much-celebrated invigoration of historical consciousness that has been constitutive of the 'historical turn' in international legal thought has been dominated by a turntablist attitude, restricting the critical potential of international lawyers' recent engagements with history.

This argument about the turntablism informing international legal studies on history proceeds as follows. After a few remarks on the 'historical turn', the chapter shows that the historical consciousness commonly associated with the 'historical turn' has long permeated the work of international lawyers and that the 'historical turn' should be better construed as a 'historiographical turn' (1). This chapter then uses the metaphor of turntablism to shed light on the confinement of international lawyers' engagement with history to the terms, vocabularies, and categories of the very historical narratives they seek to evaluate, disrupt, or displace, which it characterises as a turntablist attitude (2). It subsequently formulates a few remarks on the resilience of turntablism in international legal thought despite the critical mindset of many of the international lawyers nowadays engaging with history (3). In the final section, this chapter shows that turntablism is not the inevitable fate of international lawyers engaging with history, and that a radical historical critique is possible and should be promoted (4).

Before developing this claim about the dominant turntablist attitude in international lawyers' engagement with history, a preliminary caveat is necessary. It must be acknowledged that the discussion that unfolds in the following section is itself constitutive of a turntablist narrative that upholds the terms of markers, periodisation, and causal sequencing of dominant international lawyers' histories. ${ }^{2}$ This is well illustrated by the articulation of the discussion

2 On the constitutive elements of historical narrativisation, see generally White, Hayden. 'Historical Discourse and Literary Writing', in Tropes for the Past: Hayden White and the History/ Literature Debate, ed. Kuisma Korhonen (Amsterdam: Rodopi, 20o6), 25-34, 30; White, Hayden. Metahistory. The Historical Imagination in the 19th-Century Europe (Baltimore: Johns Hopkins University Press, 2016), 7; Barthes, Roland. 'Le discours de l'histoire'. Social Science Information 63(4) (1967), 65-75, Southgate, Beverley. 'Postmodernism', in A Companion to the Philosophy of History and Historiography, ed. Aviezer Tucker (Hoboken: Wiley-Blackwell, 2011), 548; Surkis, Judith. 'When Was the Linguistic Turn? A Genealogy'. American Historical Review 700(3) (2012), 117; Certeau, Michel de. L'écriture de l'histoire (Paris: Gallimard, 1975); Carr, Edward H. H. What is History? (Cambridge: Cambridge University Press, 2nd ed., 1987), 11; In the international legal literature, see in particular Butler, William E. 'Periodization and International Law', in Research Handbook on the Theory and History of International Law, ed. Alexander Orakhelashvili (Cheltenham: Edward Elgar, 2011), 379; Diggelman, Oliver. 'The 
that follows around the so-called 'historical turn'. The discussion that follows could thus be critically scrutinised in the very same way as it itself evaluates recent critical histories.

\section{The 'Historical Turn' as a 'Historiographical Turn'}

According to a common disciplinary narrative - for which the so-called 'historical turn' is a widespread shorthand ${ }^{3}$ - international lawyers are said to have discovered, approximately two decades ago, the merits of robust engagement with the history of international law and emancipated themselves from the linear and one-dimensional historical accounts that had been dominating the field since the end of the nineteenth century. Before that, international lawyers, as this disciplinary narrative goes, were the complacent recipients of some linear disciplinary histories inherited from the late nineteenth and early twentieth centuries, and which they were trained to reproduce while refraining from critically engaging with them. ${ }^{4}$

It is submitted here that one can hardly deny that the end of the twentieth century witnessed a rise of interest by international lawyers in the study of history, as well as enhanced suspicion towards the linear mainstream disciplinary histories of international law that had been perpetuated throughout the twentieth century. ${ }^{5}$ This change of attitude can be evidenced somewhat

Periodization of the History of International Law', in The Oxford Handbook of the History of International Law, eds. Bardo Fassbender and Anne Peters (Oxford: Oxford University Press, 2012), 996-1113, 996.

3 On the turn to history in contemporary international legal scholarship see Craven, Matthew. 'Theorizing the Turn to History in International Law', in The Oxford Handbook of the Theory of International Law, eds. Anne Orford and Florian Hoffmann (Oxford: Oxford University Press, 2016), 21-37; see also Galindo, George R. B. 'Martti Koskenniemi and the Historiographical Turn in International Law'. European Journal of International Law 16(3) (2005), 539-559, doi: 10.1093/ejil/chiızo.

4 This watershed moment is often associated with the publication of Koskenniemi, Martti. The Gentle Civilizer of Nations: The Rise and Fall of International Law (Cambridge: Cambridge University Press, 2001).

5 See Orford, Anne. 'International Law and the Limits of History', in The Law of International Lawyers: Reading Martti Koskenniemi, eds. Wouter Werner, Marieke de Hoon and Alexis Galán (Cambridge: Cambridge University Press, 2015), 297-320, 297 ('... international law has always had a deep engagement with the past. Past text and concepts are constantly retrieved and taken up as a resource in international legal argumentation and scholarship. Thus the "turn to history" trope marks a turn to history as method, rather than a turn to history in terms of engaging with the past rather than the present', ibid. 297, 307). This growing interest in the history of international law is also witnessed in relation to private international law. 
empirically, at least to the extent that the amount of scholarly publications that engage with the history of international law can plausibly constitute an indicator of greater engagement with the history of international law. ${ }^{6}$ This change of attitude can also be institutionally illustrated by reference to the creation of new scholarly journals and book series specifically dedicated to the history of international law, which have themselves been the receptacle of a prolific body of scholarship on the subject. In this context, it seems difficult to deny the change in attitude and scholarly focus, as well as the much greater engagement with the history of international law, in the international legal literature over the last two decades. ${ }^{7}$

One important dimension of the disciplinary narrative about the "historical turn' is the association of the latter with an invigoration of historical consciousness in the field. In fact, it is common for twenty-first century international lawyers to think of themselves as historically conscious and critically inclined in their engagement with history. It is true that, for instance, this 'historical turn' has brought with it unprecedented challenges to the classical linear histories inherited from the late nineteenth and early twentieth centuries in the form of counter-histories ${ }^{8}$ and greater critical or methodological

See, e.g., Banu, Roxana. Nineteenth-Century Perspectives on Private International Law (Oxford: Oxford University Press, 2018). It has been said that a historical turn has similarly been witnessed in international relations. For an illustration about the current engagement with the history of international relations, see Bell, Duncan. 'International Relations: The Dawn of a Historiographical Turn?'. British Journal of Politics and International Relations 3(1) (2001), 115126, doi:10.1111/1467-856X.ooo53; Armitage, David. 'The Fifty Years' Rift: Intellectual History and International Relations'. Modern Intellectual History 1(1) (2004), 97-109, doi:10.1017/ S1479244303000027; Schmidt, Brian. The Political Discourse of Anarchy: A Disciplinary History of International Relations (Albany: State University of New York Press, 1998); Dunne, Tim. Inventing International Society: A History of the English School (London: Palgrave Macmillan, 1998); Brown, Chris, Terry Nardin and Nicholas Rengger, eds. International Relations in Political Thought: Texts from the Ancient Greeks to the First World War (Cambridge: Cambridge University Press, 2002).

6 On the idea that the 'historical turn' has attracted less attention in Germany, see Lange, Felix. 'The Dream of a völkisch Colonial Empire: International and Colonial Law during the National Scoialist Era'. London Review of International Law 5(3) (2017), 343-369, doi:10.1093/ lril/lryoo4, 344.

7 In the same sense, and for some additional elements supporting this empirical claim, see Genin, Vincent. Le laboratoire belge du droit international. Une communauté épistémique et international de juriste (1869-1914) (Brussels: Académie Royale des sciences, des lettres et des beaux-arts de Belgique, 2018), $26-36$.

8 Koskenniemi, Gentle Civilizer 2001 (n. 4); see Kennedy, David. 'International Law and the Nineteenth Century: History of an Illusion'. Quinnipiac Law Review 17(1) (1997), 99-138, 102-103. 
scrutiny. ${ }^{9}$ Some of the fundamental markers of the discipline have also come to be questioned. For instance, the fatherhood of Grotius, ${ }^{10}$ the canonical status of his work, ${ }^{11}$ and the cosmopolitan project associated therewith, ${ }^{12}$ have

$9 \quad$ This has been one of the main purposes of those works falling under the so-called 'Third World Approaches to International Law' (TWAIL).

10 For a plea to study the precursors of Grotius as Grotius is the heir of a tradition, see Lesaffer, Randall. 'International Law and Its History: The Story of an Unrequited Love', in Time, History and International Law, eds. Matthew Craven, Malgosia Fitzmaurice and Maria Vogiatzi (Leiden: Brill, 2007), 27-42, 27, 40; see also Barreto, José-Manuel. 'Cerberus: Rethinking Grotius and the Westphalian System', in International Law and Empire, eds. Martti Koskenniemi, Walter Rech and Manuel Jiménez Fonseca (Oxford: Oxford University Press, 2017), 149-176, 154 .

11 As was discussed by Simpson, the earlier works by Grotius, and especially DeJure Praedae, seem to point in the exact opposite direction of the twentieth century progressive narrative which it is supposed to have engendered. In De Jure Praedae, Grotius distinguishes between dates on the basis of their internal politics and moral characteristics. See Simpson, Gerry. Great Powers and Outlaw States. Unequal Sovereigns in Their International Legal Order (Cambridge: Cambridge University Press, 2004), 4. See also the idea that the modernity of international law started with the Spanish age, defended by Fassbender, Bardo. 'Peace of Westphalia (1648)', in Max Planck Encyclopedia of Public International Law, ed. Rüdiger Wolfrum (Oxford: Oxford University Press, 2011), para. 19. See also the remarks of John Haskell in Haskell, John. 'Hugo Grotius in the Contemporary Memory of International Law: Secularism, Liberalism, and the Politics of Restatement and Denial', in New Approaches to International Law: The European and the American Experiences, eds. José María Beneyto and David Kennedy (The Hague: T.M.C. Asser Press, 2012), 123-15o.

On the idea of Dutch imperialism in the work of Grotius, see Barreto, 'Cerberus' 2017 (n. 11), 158 ('Grotius has not lost his place between the founding fathers of modern international law. He remains inhabiting such an Olympus, yet in another sense or for different reasons. It has been made clear that Grotius is not the founder of international law defined as a system that regulates the affairs between equal and sovereign states. Together with Vitoria, Grotius remains in the selected group of the "early parents of modern international law", a legal regime that is understood as emerging out of imperialism's needs for legitimation, and that regulated the relations between its subjects, including early modern companies'). On the idea that the writing of Grotius, like those of Gentili and Vattel, are construed as justifying 'imperial activities of their clients', see Koskenniemi, Martti. 'Introduction: International Law and Empire - Aspects and Approaches', in International Law and Empire, eds. Martti Koskenniemi, Walter Rech and Manuel Jiménez Fonseca (Oxford: Oxford University Press, 2017), 1-20, 4 (citing Israel, Jonathan. Dutch Primacy in World Trade 1585-1740 (Oxford: Clarendon, 1989), 16-17 and 69-73). For some critique of Grotius as serving the voc, see Straumann, Benjamin. "Ancient Caesarean Lawyers" in a State of Nature: Roman Tradition and Natural Rights in Hugo Grotius's De iure praedae'. Political Theory 34(3) (2006), 328-350, doi:10.1177/oogo591706286459; Jeffery, Renee. Hugo Grotius in International Thought (London: Palgrave Macmillan, 2006), 6-7; Kochi, Tarik. The Other's War. Recognition and the Violence of Ethics (London: Birkbeck Law Press, 2009), 59-6o. On Grotius and Mercantile Capitalism, see Koskenniemi, Martti. 
been severely questioned. Likewise, the very linear character of the common disciplinary histories similarly came under attack from claims that the history of international law should instead be seen as being 'pockmarked by a series of catastrophes and mutations.13

It is submitted here, however, that the association of the 'historical turn' with an invigoration of historical consciousness is rather simplistic given the fact that the Enlightenment - which provided its dualistic patterns of thought and progress narratives to international law - itself came with an unprecedented historical consciousness. ${ }^{14}$ For instance, when embarking on the creation of a disciplinary history during the professionalisation of the discipline,,$^{15}$ nineteenth and twentieth century international lawyers understood and situated

'International Law and the Emergence of Mercantile Capitalism: Grotius to Smith', in The Roots of International Law. Liber Amicorum Peter Haggenmacher, eds. Pierre-Marie Dupuy and Vincent Chetail (Leiden: Martinus Nijhoff, 2014), 1-37, 3. On the criticisms of Grotius for his neo-liberalism, see García-Salmones Rovira, Mónica. The Project of Positivism in International Law (Oxford: Oxford University Press, 2013).

13 Berman, Nathaniel. 'In the Wake of Empire'. American University International Law Review 14(6) (1999), 1521-1554, 1523 ('The genealogical approach rejects this account of international legal history as an ever-advancing dialectic of restatement and renewal. It views international legal history as pockmarked by a series of catastrophes and mutations, as rocked by the countless forms of colonial conquest and anti-colonial resistance'). At page 1524 he writes: 'International legal genealogy rejects linear accounts of the origins and progress of the international community. It recounts the forging of that community through acts of unholy matrimony, through liaisons mostly asymmetrical, even when consensual, and all-too-often irreversibly coercive and massively violent - and usually constructing the power of some patriarch or other'. See also Haskell, John. 'The Traditions of Modernity within International Law and Governance: Christianity, Liberalism, and Marxism'. Human Rights \& Globalization Law Review 6 (2015-2016), 29-5o, 37 (discussing the kinship between modernity and linear history as well as the Christian heritage).

14 White, Hayden. Metahistory. The Historical Imagination in the 19th-Century Europe (Baltimore: Johns Hopkins University Press, 2014), 51 ('The Enlightenment's own posture vis-à-vis historical writing in general was Ironic ... [It] did so in full consciousness of the possibility of a choice between so using it and practicing it for its own sake or, as it is said, for itself alone'). See also Foucault, Michel. L'archéologie de savoir (Paris: Gallimard, 1969), 23. See also Sloterdijk, Peter. Après nous le déluge (Paris: Editions Payot \& Rivages, 2016), 16; Gadamer, Hans-Georg. Truth and Method (London: Bloomsbury, 2013), xxiii; Certeau, Michel de. L'Écriture de l'Histoire (Paris: Gallimard, 1975), 15-17.

15 See Neff, Stephen.Justice among Nations (Cambridge: Harvard University Press, 2014), 304; d'Aspremont, Jean. 'The Professionalization of International Law', in International Law as a Profession, eds. Jean d'Aspremont, Tarcisio Gazzini, André Nollkaemper and Wouter Werner (Cambridge: Cambridge University Press, 2017), 19-37; Orford, Anne. 'Scientific Reason and the Discipline of International Law'. European Journal of International Law 25 (2) (2014), 369-385, doi:10.1093/ejil/chuo3o. 
themselves as agents of a disciplinary project, and demonstrated some remarkable historical consciousness. ${ }^{16}$ Indeed, it is with international law becoming a self-standing object of study in university institutions which created professorships specifically dedicated to the teaching of international law, ${ }_{17}^{17}$ as well as the primary focus of learned societies and scholarly periodicals, ${ }^{18}$ that the perceived need to endow the field with a disciplinary history became very pressing. ${ }^{19}$ For international lawyers of the time, providing a disciplinary history for international law ${ }^{20}$ proved to be a way to confirm the maturity and

16 For instance, there seems to be no doubt that Lauterpacht wrote the 'Grotian Tradition' with an acute historical self-consciousness and the ambition of writing disciplinary history. Martti Koskenniemi writes: 'Lauterpacht's oeuvre and career constitute a striking illustration of an international legal consciousness that sought to resuscitate the rationalism of the nineteenth century in the aftermath of the First World War but used up its emancipatory potential in the doctrinal struggles of the 193os.' Koskenniemi, Martti. 'Lauterpacht: The Victorian Tradition in International Law'. European Journal of International Law 8(2) (1997), 215-263, doi:10.1093/oxfordjournals.ejil.ao15565, 261. In the same sense, see Hathaway, Oona A. and Scott J. Shapiro. The Internationalists. How a Radical Plan to Outlaw War Remade the World (New York: Simon \& Schuster, 2017), 300.

17 For some general remarks on the professionalisation of international law see d'Aspremont, 'The Professionalization of International Law' 2017 (n. 16); Orford, 'Scientific Reason' 2014 (n. 16), 373; Coates, Benjamin. Legalist Empire. International Law and American Foreign Relations in the Early Twentieth Century (Oxford: Oxford University Press, 2016), 18-21, 61-68. Lapradelle, Albert G. de. De la nationalité d'origine, droit compare, droit interne, droit international (Paris: A. Giard \& E. Brièr, 1893).

18 See, e. g., the creation of the Revue générale de droit international et de legislation comparée and later the Revue générale de droit international public in 1894. See generally Neff, Justice among Nations 2014 (n. 16), 300.

19 For a famous manifestation of this feeling of a need for a disciplinary history, see Oppenheim, Lassa. 'The Science of International Law: Its Task and Method'. American Journal of International Law 2(2) (1908), 313-356, doi:10.2307/2186595. For a discussion of Oppenheim's claim, see Perreau-Saussine, Amanda. 'A Case Study on Jurisprudence as a Source of International Law: Oppenheim's Influence', in Time, History and International Law, eds. Matthew Craven, Malgosia Fitzmaurice and Maria Vogiatzi (Leiden: Brill, 2007), 1-118, 100; see also García-Salmones, The Project of Positivism 2013 (n. 13).

20 Craven, Matthew. 'The Invention of a Tradition: Westlake, The Berlin Conference and the Historicisation of International Law', in Constructing International Law: The Birth of a Discipline, eds. Luigi Nuzzo and Miloš Vec (Frankfurt: Vittorio Klostermann, 2012), 363-402. Describing this historical self-consciousness is one of the main purposes of Koskenniemi's Gentle Civilizer 2001 (n. 5). 
respectability, ${ }^{21}$ identity, ${ }^{22}$ and scientificity ${ }^{23}$ of the field, entrench it in a tradition, ${ }^{24}$ and make it a universal necessity. ${ }^{25}$ It is in this context that the first systematic and comprehensive histories of international law ${ }^{26}$ came to be produced with a great sense of historical consciousness.

For this reason, if the greater engagement with the history of international law over the last two decades, for which the 'historical turn' is a shorthand, were only 'historical', it would hardly be a turn but rather a perpetuation of the modern tradition of international law. It is argued here that the change of attitude witnessed two decades ago and dubbed the 'historical turn' marks not the historical self-consciousness of international lawyers or their historicising activities, but rather an upsurge of scholarly works discoursing and theorising about the specific forms and meanings given to the past by international lawyers and the way in which this past is written. ${ }^{27}$ Whilst international lawyers' historical consciousness could be witnessed as early as the end of the nineteenth century, the gist of the change in the discipline of international law in the last two decades lies in their greater aptitude and inclination to discourse and theorise about the specific forms and meanings which their common histories of international law have provided to the past and the way in which such a past has been created. Discoursing and theorising about the specific forms

21 Obregón, Liliana. 'Writing International Legal History: An Overview'. Monde(s) 7(1) (2015), 95-112, doi:10.3917/mond1.151.0095, 110 (she argues that this was the avowed goal of Nys).

22 Kleinlein, Thomas. 'International Legal Thought: Creation of a Tradition and the Potential of Disciplinary Self-Reflection', in The Global Community: Yearbook of International Law and Jurisprudence 2016, ed. Giuliana Ziccardi Capaldo (Oxford: Oxford University Press, 2016), 811-830, 811, 812.

23 For some critical remarks, see Orford, 'Scientific Reason' 2014 (n. 16). See also Nuzzo, Luigi. 'The Birth of an Imperial Location: Comparative Perspectives on Western Colonialism in China'. Leiden Journal of International Law 31(3) (2018), 569-596, doi:10.1017/ Sog221565180oo274, 596 .

24 Kleinlein, 'International Legal Thought' 2016 (n. 23), 816. See also Orford, 'International Law and the Limits of History' 2015 (n. 6), 307 (on the notion of invention of tradition, see Hobsbawm, Eric. 'Introduction: Inventing Traditions', in The Invention of Tradition, eds. Eric Hobsbawm and Terence Ranger (Cambridge: Cambridge University Press, 1983), 1-14).

25 Chimini, Bhupinder S. 'The Past, Present, and Future of International Law: A Critical Third World Approach'. Melbourne Journal of International Law 8(2) (2007), 499-516, 502.

26 The work of Wheaton, Laurent, and Nys quickly acquired some referential status in this respect. In the United States, James Brown Scott also invested a lot in providing the field with a disciplinary history, albeit a slightly different variant of that prevalent in Europe at the time.

27 Cf. Janne Nijman, who has called it a turn to 'history as theory'. See Nijman, Janne. 'Seeking Change by Doing History'. 24 November 2017, available at: https://ssrn.com/ abstract $=316770$, 9-10 (last accessed at 14 September 2020). 
and the meanings provided to the past and the way in which such a past is created is characteristic of what is called historiography. ${ }^{28}$ This is why the 'historical turn' is better understood as a 'historiographical turn.' ${ }^{29}$ The reference to a 'historical turn' as a shorthand for such a change of attitude of international lawyers is a misnomer. Twenty years ago, international lawyers did not wake up with an invigorated historical consciousness but, more simply, with a greater historiographical appetite.

\section{2 The 'Historical Turn' as Turntablism}

This section uses the abovementioned metaphor of turntablism to shed light on one particular dimension of the historiographical attitude that has informed international lawyers' engagement with history over the last two decades, and which has been sketched out in the previous section. It is argued here that the 'historical turn', construed here as a 'historiographical turn', has been characterised by a very strong conservatism that makes engagement with history by international lawyers look like an exercise in turntablism. In other words, this section makes the argument that the historiographical works of international lawyers in the last two decades have remained confined to the very terms, categories, and vocabularies of the histories whose creation they have been discoursing and theorising. Using the metaphor of turntablism, it is thus argued here that, while undoubtedly creating new musical effects and melodies, international lawyers have simply not changed the records on their turntables and have used the same sounds. International lawyers' engagement

28 Cf. Jenkins, Keith. On 'What is History'. From Carr and Elton to Rorty and White (Abingdon: Routledge, 1995), 16. For Keith Jenkins, historiography 'theorises both the notion of "the past" and the "writing-up" of it'.

29 Jenkins notes the interchangeable use of history and historiography in the English language. He regrets the ambiguity of English because the term history does not sufficiently distinguish between history 'as that which has been written/recorded about the past' and the past history. In English, history covers both. Hence, it would be better to use 'historiography' to refer to the writing of historians about the past. See Jenkins, Keith. Re-thinking History (London: Routledge, 2003), 7. In contrast, Edward H. H. Carr promotes an approach to history that makes it primarily historiographical. See Carr, Edward H. H. What is History? (Cambridge: Cambridge University Press, 2nd ed. 1987), 22 ('when we take up a work of history, our first concern should be not with the facts which it contains but with the historian who wrote it'). Compare with the more generic uses of these notions as the one adopted in the Companion to the Philosophy of History and Historiography, see Tucker, Aviezer. 'Introduction', in A Companion to the Philosophy of History and Historiography, ed. Aviezer Tucker (Hoboken: Wiley-Blackwell, 2011), 1-6, 2. 
with history over the last two decades has boiled down to spinning existing records differently.

The turntablism practised by those international lawyers engaging with history since the 'historical turn', and thus the confinement of international lawyers' engagement with history to the same categories, vocabularies, markers, events, texts, figures, periodisation, causalities, etc., can be illustrated as follows. Such turntablism expresses itself, for instance, in the fact that the historiographical imagination of international lawyers has continued to revolve around the same genealogical inquiries, namely whether Gentili, Vitoria, Grotius, Vattel, Lauterpacht, etc., are the spearheads, the heroes, the founding fathers, the (re-)inventers, or the heirs of the Western Enlightenment and (preor post-)modern international law. Although international lawyers today are prone to recognise that Gentili, Grotius, or Vattel may not have been the cosmopolitan humanitarians with which their status as fathers of international law endowed them, international lawyers' histories today continue to be historical narratives about Gentili, Vitoria, Grotius, Vattel, Lauterpacht, etc. ${ }^{30}$ It could even be argued that the very critical discussions of some of these 'heroes' may well have contributed to their further canonisation, for critically engaging with those considered the 'fathers' only reinforces their fatherly place in disciplinary histories. A good example of this is provided by the numerous and well-known critical engagements with the legacy of Lauterpacht that have been witnessed in the literature. Indeed, while showing the limits and contradictions of Lauterpacht's scientific cosmopolitanism, ${ }^{31}$ such studies have inevitably led to a further consolidation of Lauterpacht's stature in the linear disciplinary histories of the field. ${ }^{32}$ It could even be ventured that Lauterpacht may not have been perceived to be as much a pivotal figure as he is today until the 'historical turn' and the critical engagement therewith. ${ }^{33}$

Turntablism is also found today in the restriction of international legal scholarship to the same periodisation as mainstream histories of international law: the scholastic, the pre-modern, Westphalia, the Enlightenment, the

30 See, e.g., Yasuaki, Onuma. International Law in a Transcivilizational World (Cambridge: Cambridge University Press, 2017), 11.

31 On Lauterpacht's liberalism and modernism, see the remarks of Koskenniemi in Koskenniemi, Gentle Civilizer 2001 (n. 5), 357.

32 For an example, see e.g. the introduction by Martti Koskenniemi in Lauterpacht, Hersch. The Function of Law in the International Community (Oxford: Oxford University Press, 2nd ed., 2011). Koskenniemi writes: 'The Function of Law is the most important Englishlanguage book on international law in the 2oth century.' Ibid., xlvii. See also Koskenniemi, Gentle Civilizer 2001 (n. 4), 355-364.

33 Compare with the extent to which the discourse over the Orient is constitutive of the Occident; see Said, Edward. Orientalism (Abingdon: Routledge, 1978), 13. 
modern, colonisation, the nineteenth century, the interwar period, the postLeague of Nations, the post-Second World War, decolonisation, the cold war, the post-cold war, etc. ${ }^{34}$ It could be contended that even the agendas debated in recent historiographical literature are identical to those in previous histories: humanism, cosmopolitanism, modernism, state-centrism, voluntarism, hegemony, capitalism, etc.

Albeit surprisingly, some similar turntablism can be witnessed in the many recent post-colonial histories that have very appropriately moved attention away from the writings of Western jurists and the practice of international law in Western locations, and opened new horizons. ${ }^{35}$ Despite their immense merits and the refreshing disruption they offer, as well as all the work that still must be done in this respect, many of these studies have continued to resort to markers, periodisation, and causal sequencing all located in the West. ${ }^{36}$ Turntablism can also be found in those works that seek to emphasise non-European

34 For an illustration of the use of 1648 in historical critique, see Kennedy, David. 'Primitive Legal Scholarship'. Harvard International Law Journal 27(1) (1986), 1-98, 1-2. See the remarks of Lesaffer, 'International Law and Its History' 2007 (n. 11), 40 (he writes that even if the myth of Westphalia has been debunked, it continues to be restated again and again). See also the remarks of Koskenniemi, Martti. 'Histories of International Law: Dealing with Eurocentrism'. 16 November 2011, 5, available at: https://dspace.library.uu.nl/bitstream/handle/1874/219007/Koskenniemi_Martti _oratie.pdf (last accessed on 14 September 2020).

35 See the remarks of Benton, Lauren. 'Made in Empire: Finding the History of International Law in Imperial Locations'. Leiden Journal of International Law 31(3) (2018), 473-478, doi: 10.1017/Sog22156518000237.

36 This has been a criticism levelled by B. S. Chimni against the work of Koskenniemi. See Chimni, Bhupinder S. International Law and World Order. A Critique of Contemporary Approaches (Cambridge: Cambridge University Press, 2nd ed. 2017), 322, 327-339. See also Craven, Matthew. 'Introduction: International Law and Its Histories', in Time, History and International Law, eds. Matthew Craven, Malgosia Fitzmaurice and Maria Vogiatzi (Leiden: Brill, 2007), 1-26, 1, 12-13. This charge is not unheard of. It had already been raised against the first post-colonial histories of international law which, despite their attempt to provincialise Europe, have been criticised for reclaiming non-Western contributions within mainstream histories of international law. See, e.g., Alexandrowicz, Charles H. An Introduction to the History of the Law of Nations in the East Indies (Oxford: Clarendon Press, 1967); Alexandrowicz, Charles H. The Law of Nations in Global History (Oxford: Oxford University Press, 2017); Elias, Taslim Olawale. Africa and the Development of International Law (Leiden: Sijthoff, 1972); Anand, Ram P. Origin and Development of the Law of the Sea: History of International Law Revisited (Leiden: Martinus Nijhoff, 1983). For an overview of these works by the first generation of TWAIL scholars, see Becker Lorca, Arnulf. 'Eurocentrism in the History of International Law', in The Oxford Handbook of the History of International Law, eds. Bardo Fassbender and Anne Peters (Oxford: Oxford University Press, 2012), 1034-1048, 1034; Obregón, Liliana. 'Martti Koskenniemi's Critique of Eurocentrism in International Law', in The Law of International Lawyers: Reading Martti 
perspectives, ${ }^{37}$ for many of them re-centre non-Western locations and perspectives within a very Eurocentric history, and through European markers, periodisation, and causal sequencing. ${ }^{38}$ When they do not seek a re-centring of non-Western locations and perspectives within a very Eurocentric history, these studies continue to treat non-Western contexts as 'peripheral, ${ }^{39}$ or as a response to (or an encounter with) European or Western international law. ${ }^{40}$ What is more, some of these histories, whilst rightly lamenting the resilience of the colonial project and the mirage of universality, still pursue the project of a universal international law according to a very European idea of universality. ${ }^{41}$ By the same token, many of these histories, notwithstanding their very valuable disruptive insights, continue to rely on markers, periodisation, and causal sequencing of histories of international law built around, for instance, roman

Koskenniemi, eds. Wouter Werner, Marieke de Hoon and Alexis Galán (Cambridge: Cambridge University Press, 2015), 360-392, 360.

On this type of charge, see Liliana Obregón's comments on the occasion of her interview of Martti Koskenniemi, reproduced in Obregon, 'Martti Koskenniemi's Critique' 2015 (n. 37), 374-384 and esp. 378 .

38 A good example thereof is provided by C. H. Alexandrowicz who sought to redeem non-Western practice by showing that Grotius had been influenced by Indian Ocean maritime traditions. See Alexandrowicz, Charles H. 'Grotius and India', reproduced in Alexandrowicz, Charles H. The Law of Nations in Global History (Oxford: Oxford University Press, 2017), 113-120. For a criticism of that claim, see Armitage, David and Jennifer Pitts. “This Modern Grotius": An Introduction to the Life and Thought of C. H. Alexandrowicz', in The Law of Nations in Global History, eds. David Armitage and Jennifer Pitts (Oxford: Oxford University Press, 2017), 28-29.

39 In the same vein, see Becker Lorca, 'Eurocentrism in the History of International Law' 2012 (n. 37), 1054. It is interesting to note that Koskenniemi has tried to tone this down in Koskenniemi, Martti. 'The Case for Comparative International Law'. Finnish Yearbook of International Law 20 (2009), 1-8.

This is also a criticism made by Mohammad Shahabuddin: Shahabuddin, Mohammad. "The "Standard of Civilization" in International Law: Intellectual Perspectives from Pre-War Japan'. Leiden Journal of International Law 32(1) (2019), 13-32, doi:10.1017/Sog221565180oo559. See also Meguro, Maiko. 'Backlash against International Law by the East? How the Concent of "Transplantation" Helps Us to Better Understand Reception Processes of International Law'. Völkerrechtsblog, 11 January 2019, available at: https://voelkerrechtsblog.org/backlash -against-international-law-by-the-east/ (last accessed on 14 September 2020).

41 Speaking of the work of Bedjaoui, Anand, and Elias, Liliana Obregon argues that this first generation of TWAIL scholars viewed the solution to international law's Eurocentrism as the need to make it 'truly universal'. See Obregon, 'Martti Koskenniemi's Critique' 2015 (n. 37), 373. See also the remarks of Pahuja, Sundhya. 'The Postcoloniality of International Law'. Harvard International Law Journal 46(2) (2005), 459-469, 464 (who argues that decolonisation can be construed as the granting of a formal legal status to entities to render them commensurable with the current forms of international law). See also the remarks of Koskenniemi, 'The Case for Comparative International Law' 2009 (n. 40), 4. 
law, the scholastic, the droit public de l'Europe, the reformation, the Peace of Westphalia, the Enlightenment, the nineteenth and twentieth centuries, the encounter with European imperialism, etc. ${ }^{42}$

This being said, it would be simplistic to claim that international lawyers' engagement with history has been saturated by turntablism. Occasional critical histories that actually do away with Eurocentric markers, periodisation and causal sequencing have been witnessed. ${ }^{43}$ Among the few actual departures from Eurocentric markers, periodisation and causal sequencing of dominant histories, ${ }^{44}$ mention can be made, among others, of the recent Luis Eslava, Michael Fakhri, and Vasuki Nesiah's Bandung, Global History and International Law. Critical Pasts and Pending Futures, ${ }^{45}$ Mohammad Shahabuddin's 'The "standard of civilization" in international law: Intellectual perspectives from pre-war Japan', ${ }^{46}$ and, possibly, Robert Kolb's Esquisse d'un droit international public des anciennes cultures extra européennes. ${ }^{47}$ Yet, subject to such

42 On this point, see the remarks of Koskenniemi, 'The Case for Comparative International Law' 2009 (n. 40), 4.

43 See, e.g., Hamamoto, Shotaro. 'A propos de deux clichés sur l'histoire du droit international en asie de l'est: Une reconsidération de l'ordre mondial chinois et du discours de traités inégaux', in The Roots of International Law. Liber Amicorum Peter Haggenmacher, eds. Pierre-Marie Dupuy and Vincent Chetail (Leiden: Martinus Nijhoff, 2014), 743-756, 743. See the few other examples mentioned by Becker Lorca, 'Eurocentricism in the History of International Law' 2012 (n. 37), 1034, 1044-1048.

44 Although still trying to redeem non-Western practice through Western heroes and concepts, C. H. Alexandrowicz has tried to propose a new periodisation in the history of international law that does away with the Peace of Westphalia and is centred on 1815 , that is the time, not only of the Congress of Vienna but also the moment when the Kingdom of Poland was created. According to Alexandrowicz, this milestone is what allows the distinction between pre-nineteenth century law of nations based on natural law and universality and the positivist and European conception of international law. On this aspect of Alexandrowicz' work, see Armitage/Pitts “"Modern Grotius"' 2017 (n. 39), 19.

45 Eslava, Luis, Michael Fakhri and Vasuki Nesiah, eds. Bandung, Global History, and International Law (Cambridge: Cambridge University Press, 2017).

46 Shahabuddin, 'The "Standard of Civilization"' 2019 (n. 41), 13-32 (focusing on the preexisting hierarchical order in the Far East and highlighting the relevance of non-European regional order in the discourse on international legal history). For a criticism of the use of sources by Shahabuddin, see Meguro, Maiko. 'Backlash against International Law by the East?' 2019 (n. 41).

47 Kolb, Robert. Esquisse d'un droit international public des anciennes cultures extra européennes. Amérique précolombienne, Iles polynésiennes, Afrique noire, Sous-continent indien, Chine et régions Limitrophes (Paris: Pedone, 2010). The work of Kolb is meant to continue the work on non-Western international law initiated by Wolfgang Preiser. On the ambition of such approach to history, see the remarks of Kolb, Robert. 'Considérations sur le droit international public des anciennes cultures extra-européennes', in The Roots of International Law. Liber Amicorum Peter Haggenmacher, eds. Pierre-Marie Dupuy and 
exceptions, turntablism has been very resilient and most critical histories at work in the literature since the 'historical turn', notwithstanding their irrefutable insightfulness and sophistication, have commonly boiled down to variants of the very same markers, periodisation and causal sequencing as the ones on which dominant linear disciplinary narratives are built. They have provided very refreshing meaning-giving for mainstream linear disciplinary histories but have failed to liberate disciplinary imagination.

In the light of the foregoing, turntablism can be construed as a dominant attitude in international legal scholarship over the last two decades. The potential of the 'historical turn' does not seem to have been fully unlocked.

\section{The Resilience of Turntablism after the 'Historical Turn'}

At this stage of the discussion, it is important to highlight that the turntablism of international lawyers' engagement with the history of international law and, thus, the confinement of their recent historiographical studies to the very terms, categories, vocabularies, markers, events, texts, figures, periodisation, causalities, etc., of those narratives they are trying to question do not constitute a restriction that is unheard of. The critical historian Hayden White demonstrated how every discipline is made up of (and organised around) a set of restrictions on imagination. ${ }^{48}$ From such a perspective, it could be said that historiography cannot be the home of critique as it is bound to be articulated around the very markers, causalities, and vocabularies of the historical narratives it engages with.

It is noteworthy that international lawyers interested in critical historical inquiries have shown some reasonable awareness for the abovementioned conservatism as well as of the Eurocentric character of their inquiries. ${ }^{49}$ This is

Vincent Chetail (Leiden: Martinus Nijhoff, 2014), 673-709. It must however be stressed that the tone and presentation of this work remains very Eurocentric as those other experiences of international law are situated by reference to modern European international law.

48 White, Hayden. Tropics of Discourse: Essays in Cultural Criticism (Baltimore: Johns Hopkins University Press, 1978), 126-127.

49 Koskenniemi, Martti. 'Histories of International Law: Significance and Problems for a Critical View'. Temple International and Comparative Law Journal 27(2)(2013), 215-240, 223. See also Koskenniemi, 'The Case for Comparative International Law' 2009 (n. 40), 4; Chimni, International Law and World Order 2017 (n. 37), 322, 327-339; Becker Lorca, 'Eurocentrism in the History of International Law' 2012 (n. 37), 1044-1048; Tourme Jouannet, Emmanuelle. 'Des origines coloniales du droit international: A propos du droit des gens moderne au $18^{\text {ème }}$ siècle', in The Roots of International Law. Liber Amicorum Peter 
especially the case with Martti Koskenniemi. ${ }^{50}$ For him, international lawyers cannot deny their debt to their predecessors in terms of histories. ${ }^{51} \mathrm{He}$ has also pointed out that a total rejection of the categories and vocabularies of preceding histories would be reductive ${ }^{52}$ and that, as a result of such a rejection, international lawyers would deprive themselves of a tool to communicate 'by invoking widely shared historical associates' and building on 'shared imagination'.53 According to him, the European pedigree of the vocabularies targeted by the new histories as well as the terms, categories, vocabularies, markers, events, texts, figures, periodisation, causalities, etc., of such histories cannot be unmade. ${ }^{54}$ This is why he came to express some resignation as to the impossibility of avoiding some degree of Eurocentrism in those histories, ${ }^{55}$ even acknowledging that a critique of Eurocentrism appears to arise from European preoccupations and political beliefs. ${ }^{56}$ Critique

As was shown in the previous section, there can be good reasons for international lawyers to satisfy themselves with the limits of their historiographical studies and their turntablist attitudes. After all, the historiographical works produced since the 'historical turn', and especially those works that focus on law and empire as well as non-Western contexts, locations, and practices, have very appropriately changed the way in which international lawyers engage with history. In that sense, it cannot be denied that international lawyers' engagement with history has been dramatically transformed in the last decades. And yet, the last part of this chapter argues that international lawyers should take their

Haggenmacher, eds. Pierre-Marie Dupuy and Vincent Chetail (Leiden: Martinus Nijhoff, 2014), 649-671, 648, 670 .

50 For a thorough discussion of Martti Koskenniemi's take on Eurocentrism, see Obregón, 'Koskenniemi's Critique' 2015 (n. 37), esp. 374-384.

$5^{1} \quad$ Koskenniemi, 'Histories of International Law' 2013 (n. 50), 216.

$5^{2}$ Ibid., 224.

53 Koskenniemi, Martti. 'A History of International Law Histories', in The Oxford Handbook of the History of International Law, eds. Bardo Fassbender and Anne Peters (Oxford: Oxford University Press, 2012), 945-971, 945.

54 Koskenniemi, 'The Case for Comparative International Law' 2009 (n. 40), 4. See also Martti Koskenniemi's remarks on the occasion of the interview conducted by Liliana Obregón and reproduced in Obregón, 'Koskenniemi's Critique' 2015 (n. 37), esp. $377-384$.

Koskenniemi, 'The Case for Comparative International Law' 2009 (n. 40), 5.

56 Koskenniemi, 'Histories of International Law' 2013 (n. 50), 222. 
cue from the few critical histories that actually do away with Eurocentric markers, periodisation and causal sequencing and which have been mentioned in the previous section with a view to limiting turntablist engagement with history. It is submitted here that there is room for a more systematic radical historical critique that consists of writing and rewriting historical narratives that consciously ignore the terms, categories, vocabularies, markers, events, texts, figures, periodisation, causalities, etc., of the dominant histories. ${ }^{57}$ Such radical historical critique refers here to a critical engagement that moves beyond a mere historiographical attitude ${ }^{58}$ and does away with the terms, categories, vocabularies, markers, events, texts, figures, periodisation, causalities, etc., of the dominant histories. From the perspective of the metaphor of turntablism used in this chapter, such radical historical critique corresponds to an engagement with history where music is created not only through a different spinning of the turntables but, more radically, through the use of new records.

The plea made here for a radical historical critique - and thus for a move away from the dominant turntablism of the discipline - requires that the very idea of radical historical critique be spelled out further. The radical historical critique envisaged here boils down to a conscious intervention to redraw the past and mobilise it to serve a present claim in a way that deliberately and consciously repudiates existing terms, categories, vocabularies, markers, events, texts, figures, periodisation, causalities, etc. In that sense, radical historical critique not only entails the production of counter-histories, but calls for new modes of thinking which register the terms, categories, vocabularies, markers, events, texts, figures, periodisation, causalities, etc., of the dominant histories with a view to consciously ignoring them in a new space of narrativisation. ${ }^{59}$ Radical historical critique is thus interventionist: it registers accepted terms, categories, vocabularies, markers, events, texts, figures, periodisation, causalities, etc., and purposefully turns a blind eye to them. For that reason, using old

57 For another way to address the conservatism of counter-narratives, see Tourme Jouannet, 'Des origines coloniales du droit international' 2014 (n. 50), 670-671.

$5^{8} \quad$ Foucault, L'archéologie du savoir 1969 (n. 15), 41 (who argues that once we are freed from immediate forms of continuity, we can start constructing new statements and narratives).

59 Cf. Frederic Jameson, speaking of Adorno: 'What needs to be invented therefore - and what in my opinion Adorno's dialectics proposes - is a new kind of stereoscopic thinking in which the concept continues to be thought philosophically and cashed at face value, while in some part of the mind a very different kind of intellectual regime reigns, a cruder and more sociological set of terms and categories, in which the form of that concept is noted and registered in shorthand and in which the existence of the financial and banking system thereby presupposed is somehow reckoned in'. See Jameson, Frederic. Late Marxism. Adorno or the Persistence of the Dialectic (London: Verso, 2007), 28. 
materials in an innovative way ${ }^{60}$ falls short of such radical historical critique. It is also important to highlight that such radical historical critique cannot seek to be scientific, truth-searching, or universalist in character. ${ }^{61}$ Radical historical critique is better understood as what Rancière calls a 'poetry of knowledge' (poétique du savoir). ${ }^{62}$ It does not aim at creating a new totality or intelligibility framework. ${ }^{63}$ Radical historical critique pursues a rupture with the common historical referent of international lawyers' discourses.

Is it submitted that there is much to gain from a move towards such a radical historical critique. Such a move is about enabling the production of a wide range of new discourses about international law itself. The radical historical critique promoted here would allow international lawyers to imagine new contexts, new places, and new moments where legal claims and legal practices are made and unmade. In that sense, radical historical critique is about telling new stories filled with new actors, new turning points, new moments of rupture, new causations, new revolutionary moments, new agendas, new revolutions, new watershed moments, new crises, new infidelities, new milestones, new beginnings, new ends, new transitional periods, new genealogies, new pedigrees, new modes of liberation, new legal concepts, and new thoughts.

It must be acknowledged that embracing such a radical historical critique and discontinuing the turntablism of current legal scholarship does not constitute an easy posture. The route towards radical historical critique is not without pitfalls, some of which having been famously experienced in relation to the critique offered by those scholars affiliated with TWAIL. ${ }^{64}$ Four obstacles to the radical historical critique envisaged here must be mentioned. First,

6o This is a plea made by Koskenniemi, 'Histories of International Law' 2013 (n. 50), 240.

61 See the remarks of Anne Orford against the writing of global history: Orford, Anne. 'On International Legal Method'. London Review of International Law 1(1) (2013), 166-197, doi: 10.1093/Iril/Irtoo5. See also Orford, 'International Law and the Limits of History' 2015 (n. 6).

62 Rancière, Jacques. Les mots de l'histoire. Essai de poétique du savoir (Paris: Seuil, 1992), esp. 18-22.

63 Adorno, Theodor. Negative Dialectics (Abingdon: Routledge, 1973), 27.

64 Speaking of the work of Bedjaoui, Anand, and Elias, Liliana Obregón argues that this first general of TWAIL scholars viewed the solution to international law's Eurocentricism as the need to make it 'truly universal'. See Obregón, 'Martti Koskenniemi's Critique' 2015 (n. 37), 36o, 373. See also the remarks of Pahuja, 'The Postcoloniality of International Law' 2005 (n. 41), 464 (who argues that decolonisation can be construed as the granting of a formal legal status to entities to render them commensurable with the current forms of international law). See also the remarks of Koskenniemi, 'The Case for Comparative International Law' 2009 (n. 40), 4. For an overview of these works by the first generation of TWAIL scholars, see Becker Lorca, 'Eurocentricism in the History of International Law' 2012 (n. 37), 1034. 
there is the obstacle associated with the total loss of empirical rigour and, thus, the corresponding risk that radical historical critique veers into some disgusting revisionism. This is the risk that anything goes, which should be taken extremely seriously. In this respect, it must be pointed out that the radical historical critique envisaged here cannot be reduced to an exercise of literary creation. From the perspective of radical historical critique, engagements with history would still need to abide by some elementary empiricism and factual evidence when it comes to the materials that feed into the narrativisation concerned. It is true that the evidence and the empiricism informing the establishment of the facts populating the narrativisation would themselves be the object of discussion. Yet, those engaging with history would remain bound by those - admittedly fluctuating - constraints that apply to any argument for it to be plausible, intelligible, and acceptable for the audience that receives it. The foregoing does not mean, however, that the radical historical critique would be subject to any pre-defined methods or techniques. In particular, since such a radical critique ought to stop short of seeking to substitute one linear, progressive, scientific, true, and universal history for another, it shall certainly not espouse any pre-defined mode of investigation that is recognised as properly 'historical. ${ }^{65}$

Secondly, there are important linguistic barriers that radical historical critique must reckon with. Indeed, writing historical narratives around new markers, new figures, new locations, new places, new empires, etc., would often necessitate international lawyers going beyond their usual linguistic and cultural communities and venturing into the study of locations, contexts, and practices possibly foreign to the author of the radical historical critique. ${ }^{6}$ Such material and linguistic obstacles should not be played down or treated lightly. Yet, it is submitted here that they are not insurmountable.

Thirdly, there are important social and cultural obstacles, as those international lawyers engaging with history may simply not know other terms, categories, vocabularies, markers, events, texts, figures, periodisations, causalities, etc., than those found in the mainstream histories. It may be that they cannot think of their world outside those terms, categories, vocabularies, markers, events, texts, figures, periodisations, causalities, etc. Again, this should not sound insurmountable. If the discipline cannot have its turntablists change

65 In the same sense, see Anne Orford's plea against the idea that international lawyers should embrace 'historical methods'. See Orford, Anne. 'On International Legal Method' 2013 (n. 61), 166-197, doi:10.1093/lril//rtoo5. See also Orford, 'International Law and the Limits of History' 2015 (n. 6), 302-303 and 312.

66 See the remarks of Maiko Meguro: Meguro, 'Backlash against International Law' 2019 (n. 41). 
the records on their turntables, it is yet another reminder that new turntablists and new voices must constantly be invited to the arena. Radical historical critique necessitates a much greater opening of the stage to new voices, and especially to those trained outside the usual schools.

Finally, there is the risk of unintelligibility. In fact, the radical historical critique contemplated here, by disrupting common historical referents of international lawyers' discourses and by rejecting their terms, categories, vocabularies, markers, events, texts, figures, periodisation, causalities, etc., inevitably comes to distort intelligibility frameworks and, thus, bring about unintelligibility in historical discourses. This is the risk of cacophony. Yet, it is submitted here that such unintelligibility should not be feared or viewed in a dim light. Indeed, the intelligibility of current histories should not be exaggerated, for many of the histories found in the international legal literature rest on impressions of intelligibility. What is more, the loss of some degree of intelligibility of the historical discourses that would follow the radical historical critique advocated here constitutes a form of disobedience characteristic of critique. ${ }^{67}$

Because these obstacles, although very serious, are deemed here to be surmountable, it is argued at the ultimate stage of this chapter that the turntablism discussed in section 2, and notwithstanding the forces that make it so resilient and that were mentioned in section 3, ought not to constitute the dominant attitude of international lawyers engaging with history. Indeed, as is illustrated by the few works that depart from the Eurocentric terms, vocabularies, and categories of the dominant histories and which have been mentioned in section 2, there is room for a critical engagement with history that, as described in section 4 , moves beyond a mere historiographical attitude ${ }^{68}$ and does away with the terms, categories, vocabularies, markers, events, texts, figures, periodisation, causalities, etc., of the dominant histories. Such radical historical critique is not an end in itself but should arguably be pursued as a means to unlock the full potential of the 'historical turn' in international law. Said in terms of the metaphor of turntablism used in this chapter, exploiting the full potential of the 'historical turn' in international law requires that international lawyers engaging with history load new records on their turntables in order to start producing new sounds and new melodies, enabling the ravers in the arena to liberate their imagination, their discourses, and their worlds of possibilities.

67 On the idea of disobeying the totality, see Adorno, Theodor. The Positivist Dispute in German Sociology (New York: Harper Torchbooks, 1976), 12.

68 Foucault, L'archéologie du savoir 1969 (n. 15), 41 (who argues that once we are freed from immediate forms of continuity, we can start constructing new statements and narratives). 


\section{Acknowledgement}

The author thanks Tim Clark for his assistance.

\section{Bibliography}

Adorno, Theodor. Negative Dialectics (Abingdon: Routledge, 1973).

Adorno, Theodor. The Positivist Dispute in German Sociology (New York: Harper Torchbooks, 1976).

Alexandrowicz, Charles H. An Introduction to the History of the Law of Nations in the East Indies (Oxford: Clarendon, 1967).

Alexandrowicz, Charles H. The Law of Nations in Global History (Oxford: Oxford University Press, 2017).

Anand, Ram R. P. Origin and Development of the Law of the Sea: History of International Law Revisited (Leiden: Martinus Nijhoff, 1983).

Armitage, David and Pitts, Jennifer. “This Modern Grotius": An Introduction to the Life and Thought of C. H. Alexandrowicz', in The Law of Nations in Global History, eds. David Armitage and Jennifer Pitts (Oxford: Oxford University Press, 2017).

Armitage, David. 'The Fifty Years' Rift: Intellectual History and International Relations'. Modern Intellectual History 1(1) (2004), 97-109.

d'Aspremont, Jean. 'The Professionalization of International Law', in International Law as a Profession, eds. Jean d'Aspremont, Tarcisio Gazzini, André Nollkaemper and Wouter Werner (Cambridge: Cambridge University Press, 2017), 19-38.

Banu, Roxana. Nineteenth-Century Perspectives on Private International Law (Oxford: Oxford University Press, 2018).

Barreto, José-Manuel. 'Cerberus: Rethinking Grotius and the Westphalian System', in International Law and Empire, eds. Martti Koskenniemi, Walter Rech and Manuel Jimenez Fonseca (Oxford: Oxford University Press, 2017), 149-176.

Barthes, Roland. 'Le discours de l'histoire'. Social Science Information 63(4) (1967), 65-75.

Becker Lorca, Arnulf. 'Eurocentricism in the History of International Law', in The Oxford Handbook of the History of International Law, eds. Bardo Fassbender and Anne Peters (Oxford: Oxford University Press, 2012), 1034-1048.

Bell, Duncan. 'International Relations: The Dawn of a Historiographical Turn?'. British Journal of Politics and International Relations 3(1) (2001), 115-126.

Benton, Lauren. 'Made in Empire: Finding the History of International Law in Imperial Locations'. Leiden Journal of International Law 31(3) (2018), 473-478.

Berman, Nathaniel. 'In the Wake of Empire'. American University International Law Review 14(6) (1999), 1521-1554. 
Brown, Chris, Terry Nardin and Nicholas Rengger, eds. International Relations in Political Thought: Texts from the Ancient Greeks to the First World War (Cambridge: Cambridge University Press, 2002).

Butler, William E. 'Periodization and International Law', in Research Handbook on the Theory and History of International Law, ed. Alexander Orakhelashvili (Cheltenham: Edward Elgar, 2011), 379-393.

Carr, Edward H. What is History? (Cambridge: Cambridge University Press, 2nd ed. 1987).

Certeau, Michel de. L'écriture de l'histoire (Paris: Gallimard, 1975).

Chimini, Bhupinder S. International Law and World Order. A Critique of Contemporary Approaches (Cambridge: Cambridge University Press, 2nd ed. 2017).

Chimini, Bhupinder S. 'The Past, Present, and Future of International Law: A Critical Third World Approach'. Melbourne Journal of International Law 8(2) (2007), 499-516.

Coates, Benjamin. Legalist Empire. International Law and American Foreign Relations in the Early Twentieth Century (Oxford: Oxford University Press, 2016).

Craven, Matthew. 'Introduction: International Law and Its Histories', in Time, History and International Law, eds. Matthew Craven, Malgosia Fitzmaurice and Maria Vogiatzi (Leiden: Brill, 2007), 1-26.

Craven, Matthew. 'The Invention of a Tradition: Westlake, The Berlin Conference and the Historicisation of International Law', in Constructing International Law: The Birth of a Discipline, eds. Luigi Nuzzo and Miloš Vec (Frankfurt am Main: Vittorio Klostermann, 2012), 363-402.

Craven, Matthew. 'Theorizing the Turn to History in International Law', in The Oxford Handbook of the Theory of International Law, eds. Anne Orford and Florian Hoffmann (Oxford: Oxford University Press, 2016), 21-37.

Diggelman, Oliver. 'The Periodization of the History of International Law', in The Oxford Handbook of the History of International Law, eds. Bardo Fassbender and Anne Peters (Oxford: Oxford University Press, 2012), 997-1113.

Dunne, Tim. Inventing International Society: A History of the English School (London: Macmillan, 1998).

Fassbender, Bardo. 'Peace of Westphalia (1648)', in Max Planck Encyclopedia of Public International Law, ed. Rüdiger Wolfrum (Oxford: Oxford University Press, 2011), available at: https://opil.ouplaw.com/view/10.1093/law:epil/978019923169o/law978019923169o-e739?rskey=rwa8dV\&result=1\&prd=MPIL (last accessed on 14 September 2020).

Foucault, Michel. L'archéologie du savoir (Paris: Gallimard, 1969).

Gadamer, Hans-Georg. Truth and Method (London: Bloomsbury, 2013), xxiii.

Galindo, George R. B. 'Martti Koskenniemi and the Historiographical Turn in International Law'. European Journal of International Law 16(3) (2005), 539-559, doi: 10.1093/ejil/chi1zo. 
García-Salmones Rovira, Mónica. The Project of Positivism in International Law (Oxford: Oxford University Press, 2013).

Genin, Vincent. Le laboratoire belge du droit international. Une communauté épistémique et international de jurists (1869-1914) (Brussels: Académie royale des sciences, des lettres et des beaux-arts de Belgique, 2018).

Hamamoto, Shotaro. 'A propos de deux clichés sur l'histoire du droit international en asie de l'est: Une reconsidération de l'ordre mondial chinois et du discours de traités inégaux', in The Roots of International Law. Liber Amicorum Peter Haggenmacher, eds. Pierre-Marie Dupuy, Vincent Chetail (Leiden: Martinus Nijhoff, 2014), 743-756.

Haskell, John. 'Hugo Grotius in the Contemporary Memory of International Law: Secularism, Liberalism, and the Politics of Restatement and Denial', in New Approaches to International Law: The European and the American Experiences, eds. José María Beneyto and David Kennedy (The Hague: T.M.C. Asser Press, 2012), 123-150.

Haskell, John. 'The Traditions of Modernity within International Law and Governance: Christianity, Liberalism, and Marxism'. Human Rights \& Globalization Law Review 6 (2015-2016), 29-50.

Hathaway, Oona A. and Scott J. Shapiro. The Internationalists. How a Radical Plan to Outlaw War Remade the World (New York: Simon \& Schuster, 2017).

Hobsbawm, Eric. 'Introduction: Inventing Traditions', in The Invention of Tradition, eds. Eric Hobsbawm and Terence Ranger (Cambridge: Cambridge University Press, 1983), 1-15.

Holmes, Thom. Electronic and Experimental Music: Technology, Music, and Culture (Abingdon: Routledge, 2015), 476-483.

Israel, Jonathan. Dutch Primacy in World Trade 1585-1740 (Oxford: Clarendon Press, 1989).

Jameson, Frederic. Late Marxism. Adorno or the Persistence of the Dialectic (London: Verso, 2007).

Jeffery, Renee. Hugo Grotius in International Thought (London: Palgrave Macmillan, 2006).

Jenkins, Keith. On 'What is History'. From Carr and Elton to Rorty and White (London: Routledge, 1995).

Jenkins, Keith. Re-thinking History (Abingdon: Routledge, 2003).

Kennedy, David. 'Primitive Legal Scholarship'. Harvard International Law Journal 27(1) (1986), 1-98.

Kleinlein, Thomas. 'International Legal Thought: Creation of a Tradition and the Potential of Disciplinary Self-Reflection', in The Global Community: Yearbook of International Law and Jurisprudence 2016, ed. Giuliana Ziccardi Capaldo (Oxford: Oxford University Press, 2016), 811-830. 
Kochi, Tarik. The Other's War. Recognition and the Violence of Ethics (London: Birkbeck Law Press, 2009).

Kolb, Robert. Esquisse d'un droit international public des anciennes cultures extra européennes. Amérique précolombienne, Iles polynésiennes, Afrique noire, sous-continent indien, Chine et régions limitrophes (Paris: Pedone, 2010).

Kolb, Robert. 'Considérations sur le droit international public des anciennes cultures extra-européennes', in The Roots of International Law. Liber Amicorum Peter Haggenmacher, eds. Pierre-Marie and Vincent Chetail (Leiden: Martinus Nijhoff, 2014), 673-709.

Koskenniemi, Martti. The Gentle Civilizer of Nations. The Rise and Fall of International Law 1870-1960 (Cambridge: Cambridge University Press, 2001).

Koskenniemi, Martti. 'A History of International Law Histories', in The Oxford Handbook of the History of International Law, eds. Bardo Fassbender and Anne Peters (Oxford: Oxford University Press, 2012), 945-971.

Koskenniemi, Martti. 'Histories of International Law: Dealing with Eurocentrism'. 16 November 2011, available at: https://dspace.library.uu.nl/bitstream/handle/1874/ 219007/Koskenniemi_Martti_oratie.pdf (last accessed on 14 September 2020).

Koskenniemi, Martti. 'Histories of International Law: Significance and Problems for a Critical View'. Temple International and Comparative Law Journal 27(2) (2013), 215-240.

Koskenniemi, Martti. 'International Law and the Emergence of Mercantile Capitalism: Grotius To Smith', in The Roots of International Law. Liber Amicorum Peter Haggenmacher, eds. Pierre-Marie Dupuy and Vincent Chetail (Leiden: Martinus Nijhoff, 2014), 1-37.

Koskenniemi, Martti. 'Introduction: International Law and Empire - Aspects and Approaches', in International Law and Empire, eds. Martti Koskenniemi, Walter Rech and Manuel Jimenez Fonseca (Oxford: Oxford University Press, 2017), 1-20.

Koskenniemi, Martti. 'Lauterpacht: The Victorian Tradition in International Law' EuropeanJournalofInternationalLaw8(2)(1997),215-263, doi:10.1093/oxfordjournals .ejil.ao15565, 261.

Koskenniemi, Martti. 'The Case for Comparative International Law'. Finnish Yearbook of International Law 20 (2009), 1-8.

Lange, Felix. 'The Dream of a völkisch Colonial Empire: International Law and Colonial Law during the Nation Socialist Era'. London Review of International Law 5(3) (2017), 343-369, doi:10.1093/lril/lryoo4, 344.

Lapradelle, Albert G. de. De la nationalité d'origine, droit compare, droit interne, droit international (Paris: A. Giard \& E. Brièr, 1893).

Lauterpacht, Hersch. The Function of Law in the International Community (Oxford: Oxford University Press, 2nd ed. 2011). 
Lesaffer, Randall. 'International Law and Its History: The Story of an Unrequited Love', in Time, History and International Law, eds. Matthew Craven, Malgosia Fitzmaurice and Maria Vogiatzi (Leiden: Brill, 2007), 27-42.

Meguro, Maiko. 'Backlash against International Law by the East? How Concept of "Transplantation" Helps Us to Better Understand Reception Processes of International Law'. Völkerrechtsblog, 11 January 2019, available at: https:// voelkerrechtsblog.org/backlash-against-international-law-by-the-east/ (last accessed on 14 September 2020).

Neff, Stephen. Justice among Nations (Cambridge: Harvard University Press, 2014).

Nijman, Janne. 'Seeking Change by Doing History'. 24 November 2017, available at: https://ssrn.com/abstract=316770 (last accessed on 14 September 2020).

Nuzzo, Luigi. 'The Birth of an Imperial Location: Comparative Perspectives on Western Colonialism in China'. Leiden Journal of International Law 31(3) (2018), 569-596, doi: 10.1017/Sog22156518000274.

Obregón, Liliana. 'Martti Koskenniemi's Critique of Eurocentrism in International Law', in The Law of International Lawyers: Reading Martti Koskenniemi, eds. Wouter Werner, Marieke de Hoon and Alexis Galán (Cambridge: Cambridge University Press, 2015), 36o-392.

Obregón, Liliana. 'Writing International Legal History: An Overview'. Monde(s) 7(1) (2015), 95-112, doi:10.3917/mond1.151.0095.

Oppenheim, Lassa. 'The Science of International Law: Its Task and Method'. American Journal of International Law 2(2) (1908), 313-356, doi:10.2307/2186595.

Orford, Anne. 'International Law and the Limits of History', in The Law of International Lawyers: Reading Martti Koskenniemi, eds. Wouter Werner, Marieke de Hoon and Alexis Galán (Cambridge: Cambridge University Press, 2015), 297-320.

Orford, Anne. 'On International Legal Method'. London Review of International Law 1(1) (2013), 166-197, doi:10.1093/lril/lrtoo5.

Orford, Anne. 'Scientific Reason and the Discipline of International Law'. European Journal of International Law 25(2) (2014), 369-385, doi:10.1093/ejil/chuo3o.

Pahuja, Sundhya. 'The Postcoloniality of International Law'. Harvard International Law Journal 46(2) (2005), 459-469.

Perreau-Saussine, Amanda. 'A Case Study on Jurisprudence as a Source of International Law: Oppenheim's Influence', in Time, History and International Law, eds. Matthew Craven, Malgosia Fitzmaurice and Maria Vogiatzi (Leiden: Brill, 2007), 91-118.

Rancière, Jacques. Les mots de l'histoire. Essai de poétique du savoir (Paris: Seuil, 1992).

Said, Edward. Orientalism (Abingdon: Routledge, 1978).

Schmidt, Brian. The Political Discourse of Anarchy: A Disciplinary History of International Relations (Albany: State University of New York Press, 1998). 
Shahabuddin, Mohammad. "The "Standard of Civilization" in International Law: Intellectual Perspectives from Pre-War Japan'. Leiden Journal of International Law 32(1) (2019), 13-32.

Simpson, Gerry. Great Powers and Outlaw States. Unequal Sovereigns in Their International Legal Order (Cambridge: Cambridge University Press, 2004).

Sloterdijk, Peter. Après nous le déluge (Paris: Editions Payot \& Rivages, 2016).

Southgate, Beverley. 'Postmodernism', in A Companion to the Philosophy of History and Historiography, ed. Aviezer Tucker (Hoboken: Wiley-Blackwell, 2011), 540-549.

Straumann, Benjamin. “Ancient Caesarean Lawyers” in a State of Nature: Roman Tradition and Natural Rights in Hugo Grotius's De iure praedae'. Political Theory 34(3) (2006), 328-35o, doi:10.1177/oogo591706286459.

Surkis, Judith. 'When Was the Linguistic Turn? A Genealogy'. American Historical Review $117(3)$ (2012), 700-723.

Taslim Olawale, Elias. Africa and the Development of International Law (Leiden: Sijthoff, 1972).

Tourme Jouannet, Emmanuelle. 'Des origines coloniales du droit international: A propos du droit des gens moderne au $18^{\text {ème }}$ siècle', in The Roots of International Law. Liber Amicorum Peter Haggenmacher, eds. Pierre-Marie Dupuy and Vincent Chetail (Leiden: Martinus Nijhoff, 2014), 649-671.

Tucker, Aviezer. 'Introduction', in A Companion to the Philosophy of History and Historiography, ed. Aviezer Tucker (Hoboken: Wiley-Blackwell, 2011), 1-6.

White, Hayden. Metahistory. The Historical Imagination in the 19th-Century Europe (Baltimore: Johns Hopkins University Press, 2014).

White, Hayden. Tropics of Discourse: Essays in Cultural Criticism (Baltimore: Johns Hopkins University Press, 1978).

White, Hayden. 'Historical Discourse and Literary Writing', in Tropes for the Past: Hayden White and the History/Literature Debate, ed. Kuisma Korhonen (New York: Rodopi, 2006), 25-34.

Yasuaki, Onuma. International Law in a Transcivilizational World (Cambridge: Cambridge University Press, 2017). 